\title{
The Effect of Low Impact and Mixed Impact Aerobic Exercise on Percentage of Body Fat
}

\author{
Umar Nawawi ${ }^{1}$ \\ ${ }^{1}$ Faculty of Sports Science, Universitas Negeri Padang, Indonesia \\ Correspondence: Umar Nawawi, Faculty of Sports Science, Universitas Negeri Padang, Jl. Prof. Dr. Hamka - \\ Air Tawar, Padang, Sumatera Barat, Indonesia. E-mail: umarnawawi25@yahoo.com
}

Received: February 12, 2014 Accepted: February 20, 2014 Online Published: February 28, 2014

doi:10.5539/ass.v10n5p163

URL: http://dx.doi.org/10.5539/ass.v10n5p163

\begin{abstract}
This study aimed to investigate the effect of low impact aerobic exercise and mixed impact aerobic exercise on lowering percentage of body fat. Many people have difficulty to stay away from overweight (obesity). It is widely known that obesity is commonly caused by over fat in the body. The populations of this research were female students of Faculty of Sport Science, Universitas Negeri Padang, while the samples were female students Department of Coaching Education. 20 female students were selected using purposive sampling technique to be the samples. Group 1 was treated with low impact aerobic exercises and group 2 was treated with mixed impact aerobic exercise. A total of 16 exercise sessions were given to the groups as treatments. The instrument used to find out the decrease of fat was Fitness Calculator. Data analysis and interpretation indicate that low impact aerobic exercise can lower body fat percentage $(\mathrm{t}=4.910, \mathrm{p}<0.05)$, mixed impact aerobic exercise can lower body fat percentage $(\mathrm{t}=5.110, \mathrm{p}<0.05)$, and there is no difference between the effect of low impact aerobic exercises and the mixed impact aerobic exercise on declining the percentage of body fat $(\mathrm{t}=1.020, \mathrm{p}>0.05)$.
\end{abstract}

Keywords: aerobic, low impact, mixed impact, body fat percentages

\section{Introduction}

Advancement of the science and technology today is found to be very helpful for many aspects of life. It can make work more effective and efficient. However, it can also be bad for health and fitness that may lead to hypokinesia (lack of movement). Many people are dependent of transport to go anywhere including going to higher floor of a building using elevator. This condition is worsen if they often consume high-calorie foods because it may cause imbalance of calories (more calories in than out) and it may lead to obesity (overweight).

Obesity may not only cause overweight but also other severe effects. It could lead to the emergence of a variety of degenerative diseases such as coronary heart disease, hypertension, diabetes mellitus, and rheumatism. In addition, obesity could affect the physical appearance, such as slow body movement and less attractive look. Moore says that "health problem caused by obesity are cardiovascular disorders such as hypertension and coronary heart disease, and respiratory problems.

Lot of things can be done to avoid obesity, such as, doing regular physical exercise, regulating food consumption, avoiding alcoholic beverages, and having adequate rest. This study aimed to investigate the effect of low impact aerobic exercise and mixed impact aerobic exercise on lowering percentage of body fat.

Fats are organic compounds consisting of carbon atoms $(\mathrm{C})$, hydrogen $(\mathrm{H})$, and oxygen $(\mathrm{O})$. Fat with high melting point and solid at room temperature are called fat, while the one with low melting point is called oil (Depkes, 2007). Hydrolyzed fats will produce one molecule of glycerol and three fatty acids. Indonesian Department of Health (2007) has indicated that fatty acid consists of:

1) unsaturated fatty acids (vegetable oils), found in sesame oil, corn oil, olive oil, peanut oil, vegetable oil, and in abundant of fruits, such as avocados and bananas.

2) saturated fatty acids (animal fat), found in egg yolks, beef, mutton, milk, butter and coconut oil. Consuming high animal fat will increase blood cholesterol that may lead to coronary heart disease.

Fat tissue consists of fat cells that may increase in number during childhood and are influenced by some factors such as diet and exercise habits. Usually, the number of fat cells remains stable after puberty. When excess 
carbohydrate in the diet is not needed by the body, then it is converted by the body into fat and stored as a backup energy which can be use at any time when needed by the body. The fat reserves will primarily be stored under the skin, around muscles, heart, lungs, kidneys, and other organs.

Thickness of body fat is defined as the presence of fatty tissue under the skin folds, but it is not called cholesterol. Body fat is expressed as percentage (\%) of the value of total body weight. Body fat percentage can be measured indirectly through the measurement of skin fold thickness in different parts of the body using skinfold callipers. The categories for body fat percentages is shown in Table 1 .

Table 1. Body fat percentage

\begin{tabular}{|c|c|c|}
\hline Level & Male (\%) & Female (\%) \\
\hline Athletic & $6-10$ & $10-15$ \\
\hline Good & $11-14$ & $16-19$ \\
\hline Acceptable & $15-18$ & $20-25$ \\
\hline Overweight & $19-24$ & $26-29$ \\
\hline Obese & 25 or more & 30 or more \\
\hline
\end{tabular}

Source: William (2002) in Wita Rizki Amelia, FKM UI 2009

Obesity, also known as overweight is not a new thing among the Indonesian society. Septiyadi (2004) states that obesity is well known as a contributing factor for degenerative diseases such as hypertension (high blood pressure), diabetes mellitus, and coronary heart diseases. Obesity is caused by factors such as excessive food intake where the amount of food eaten each day is much more than what is needed by the body. Snack, regardless of the amount, contributes to excessive food intake if it is done continuously as a habit. Lack of regular exercise can also be the cause of obesity, whereby physical activity is very rarely done, which leads to lack of movement (hypokinesia).

Emotional disturbance because of psychological stress or perceived environmental community life is not conducive can change people's personality and some of them will turn to food as a solution. This leads to excessive food intake. Heredity may influence obesity. The actual influence is not yet clear, but there is evidence supporting the fact that parents may be a factor of obesity. Sumanto (2009) states that a person who was born from either fat parent is $40 \%$ likely to be fat and it can be $80 \%$ if the both parents were fat. Basal metabolic rate of each person is not the same. Some people have high basal metabolism, but others do not. People who have low metabolic rate tend to be heavier than people who have high metabolism since the low metabolism, results in low energy consumption, and fat is broken down to glycogen at a slower rate. As a result, more fat is stored in the body. Some medicines taken by patients may stimulate the "feeling of hunger" and increases their appetite. Taking the medication over a long period of time may cause obesity. In addition, birth control pills can also cause gradual weight gain for women.

Exercise is a physical activity intended to improve physical state, technique, tactics /strategy and mental. How physical exercise is carried out depends on the objectives to be achieved. Therefore, physical activities should be structured in such away in accordance with the objectives.

Aerobics are exercise done accompanied by music. Movement in aerobics is adjusted to the rhythm of the music. According to Sorensens, "Aerobics is a complete program of physical fitness, including exercise and excitement to express all the feelings by laughing, jumping, kicking, jogging, stretching, swaying with the movement of dance or movements which combines traditional dance, folk dance, and contemporary dance". In addition, Dr. Kenneth Cooper in Mulyono (2011) states that the concept of musical rhythm and regular movement enable the body to pump oxygen to increase heart rate. Aerobic exercise is any activity or exercise that demands more oxygen to extend the time and force the body to be active.

Judging from the forms of movement and rhythm of the music, aerobics consist of various type, namely, low impact aerobics, high-impact aerobics, mixed impact aerobics (a mixture of low and high impact), dangdut (traditional) aerobics, disco aerobics, sport aerobics, and funky aerobics.

Furthermore, according to Mulyono (2011), aerobic exercise can improve the durability of the heart and lungs. It is also good to burn excess fat in the body, strengthen and build muscles and other body parts, such as waist, thighs, hips, and abdomen. 


\section{Methodology}

This is a quasi-experimental research with low impact and mixed impact aerobic exercises as the independent variables and the percentage of body fat as the dependent variable. The populations of this research were female students of Faculty of Sport Science, Universitas Negeri Padang, while samples were female students from Department of Coaching Education. A total of 20 students were chosen as samples using purposive sampling technique.

For this research, low impact aerobic exercise is defined as a low movement exercises accompanied by a light beat slow music, while mixed impact aerobics are aerobics mixed with low impact and high-impact aerobics and musical accompaniment is a mixture of slow and fast music. Body fat percentage is defined as the thickness of fat tissue under the skin. When someone has excess of energy derived from fat, the excess will be stored under the skin in the form of body fat. Fitness Calculator was used to determine the percentage of body.

The treatments were low impact aerobic exercises for group 1 and mixed impact aerobic exercises for group 2. Each group was given treatment (exercise) in accordance with the training program for 16 times, 3 times a week. Pretest was conducted before the exercise and posttest was conducted at the end of the training.

The instrument used to measure body fat percentage is the Fitness Calculator. The results were then compared with the body fat percentage tables shown in Table 2 .

$\begin{array}{ll}\text { High: } & \text { ( ) } \mathrm{Cm} \\ & \text { ( ) Inci } \\ \text { Neck: } & \text { ( ) } \mathrm{Cm} \\ & \text { ( ) Inci } \\ \text { Waist: } & \text { ( ) } \mathrm{Cm} \\ & \text { () Inci }\end{array}$

$\begin{array}{ll}\text { Hip (female): } & \text { ( ) } \mathrm{Cm} \\ & \text { ( ) Inci }\end{array}$

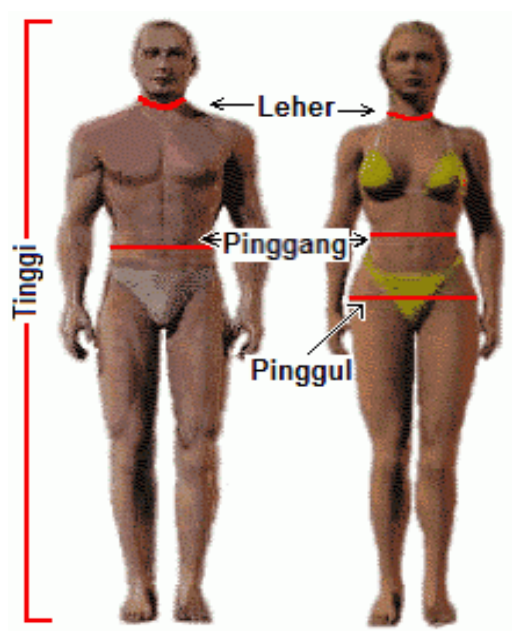

Weight: ( ) $\mathrm{Kg}$

( ) $\mathrm{Lb}$

Sex:

() Pria

( ) Wanita

Age: ( ) Year

Activity: Kurang (tidak atau sedikit berolahraga)

Sedikit aktif (olahraga/latihan ringan 1-3 hari/minggu)

Cukup aktif (olahraga/latihan cukup 3-5 hari/minggu)

Sangat aktif (olahraga/latihan berat 6-7 hari/minggu)

Ekatra aktif (olahraga/latihan sangat berat 2 session/hari atau pekerja kasar)

Table 2. Body fat percentage

\begin{tabular}{ccll}
\hline & Fat Percentage: & & \\
Female & Male & Status \\
\hline $10-12$ & $2-4$ & Essential fat & \\
$14-20$ & $6-13$ & Athlete & \\
$21-24$ & $14-17$ & Fitness \\
$25-31$ & $18-25$ & Acceptable \\
$32 \%$ more & $26 \%$ more & Obese \\
\hline
\end{tabular}

The data collected and were height, weight, age, gender, neck circumference, waist circumference and hip 
circumference. The data obtained from measurements of body fat percentage were analyzed by t-test.

\section{Results}

Table 3 shows the result of data analysis conducted. Based on the data analysis and interpretation, it can be concluded that there is a significant effect of low impact aerobic exercise on the percentage of body fat $(\mathrm{t}=4.910$, $\mathrm{p}<0.05$ )

Table 3. Paired samples test

\begin{tabular}{|c|c|c|c|c|c|c|c|}
\hline & \multirow{3}{*}{ Mean } & \multicolumn{4}{|c|}{ Paired Differences } & \multirow{3}{*}{$\mathrm{t} \quad \mathrm{df}$} & \multirow{3}{*}{$\begin{array}{c}\text { Sig. } \\
\text { (2-tailed) }\end{array}$} \\
\hline & & \multirow{2}{*}{$\begin{array}{c}\text { Std. } \\
\text { Deviation }\end{array}$} & \multirow{2}{*}{$\begin{array}{l}\text { Std. Error } \\
\text { Mean }\end{array}$} & \multicolumn{2}{|c|}{$\begin{array}{l}95 \% \text { Confidence Interval of } \\
\text { the Difference }\end{array}$} & & \\
\hline & & & & Lower & Upper & & \\
\hline $\begin{array}{l}\text { Pretest Low Impact - } \\
\text { Posttest Low Impact }\end{array}$ & 1.3700 & 1.1814 & .3736 & .5249 & 2.2151 & 4.9109 & .001 \\
\hline $\begin{array}{l}\text { Pretest Mixed Impact - } \\
\text { Posttest Mixed Impact }\end{array}$ & 1.7000 & .7242 & .2290 & 1.1819 & 2.2181 & 5.1109 & .001 \\
\hline $\begin{array}{l}\text { Posttest Low Impact - } \\
\text { Posttest Mixed Impact }\end{array}$ & .4100 & 1.9644 & .6212 & -.9952 & 1.8152 & 1.0209 & .334 \\
\hline
\end{tabular}

The second analysis showed that there is a significant effect of mixed impact aerobic exercise on the percentage of body fat $(\mathrm{t}=5.110, \mathrm{p}<0.05)$. The third analysis showed that there is no significant difference between low impact and mixed impact aerobics exercises on the percentage of body fat $(\mathrm{t}=1.020, \mathrm{p}>0.05)$.

\section{Conclusion}

The result of data analysis indicates that the first hypothesis is accepted. There is an effect of low impact aerobic exercises on the decrease in body fat percentage. This may be caused by the intensity of the exercise. Since low impact aerobic system of energy is more dominant, it is influential enough to burn fat in the body. In addition, the samples that did the exercise were also given a list of menus that must be consumed during the exercise program. Mixed impact aerobic exercise can also cause maximum fat burning. Meanwhile, the third hypothesis stating that there is a difference between low impact aerobic exercise and high impact aerobic exercise on the percentage of body fat was rejected. Rejection of the third hypothesis is probably due to the amount of exercise performed by the sample is not enough to cause a difference.

It can be concluded that both aerobic exercises (low and mixed impact) can be used to decrease percentage of body fat. In order to make it more effective, it must be accompanied by consuming certain diets in accordance with previously determined menus.

\section{References}

AnekaFitness. (n. d.). Retrieved from http://anekafitness.com/kalkulator-aneka-fitness.htm

Depdiknas. (2000). Pedoman dan Modul Pelatihan Kesehatan Olahraga. Jakarta: Pusat Pengembangan Kualitas Jasmani,

Depkes. (2007). Gizi dan Kesehatan Masyarakat. Jakarta: Raja Grafindo Persada.

Mulyono. (2011). Retrieved

from http://central-education.blogspot.com/2011/10/pengertian-danmanfaat-senamaerobik.html

Scientific Psychic. (n. d.). Diet kalkulator dan Lemak Badan Kalkulator. Retrieved from http://www.scientificpsychic.com/fitness/diet-kalkulator-id.html

Septiyadi, E. (2004). Terapi Obesitas dengan Diet. Jakarta: Restu Agung.

Sumanto, A. (2009). Tetap Langsing dan Sehat Dengan Terapi Diet. Jakarta: PT. Argomsedia Pustaka. 


\section{Copyrights}

Copyright for this article is retained by the author(s), with first publication rights granted to the journal.

This is an open-access article distributed under the terms and conditions of the Creative Commons Attribution license (http://creativecommons.org/licenses/by/3.0/). 